\title{
Upgrading the Navigable Channels along the River Nile within Egypt for
}

\section{Satisfying New Transportation Requirements}

\author{
Wael Ahmed Fahmy ${ }^{1}$, Nasr Tawfik Hassan Hekal ${ }^{2}$ \\ ${ }^{1}$ Lecturer, Civil Engineering Department, Shoubra Faculty of Engineering, Benha University, E-mail: \\ wael.ahmed@feng.bu.edu.eg, wailfamy@yahoo.com \\ ${ }^{2}$ Ass., Professor at Nile Research Institute, National Water Research Center, \\ Email: nasr_hekal@nwrc.gov.eg, nasrhekal@gmail.com
}

\begin{abstract}
This research mainly aims to upgrade the navigable channels established along the River Nile main waterway and its branches within Egypt to satisfy the inland river transportation requirements. The upgrade targets re-design of safe navigable channels along river straight and meandering segments. Also, the paper aims to identify the safest design approach developed so far. River main waterway and other 3 branches were taken as study areas. Representative design ships used are of $100 \mathrm{~m}$ length and 15 and $11.6 \mathrm{~m}$ widths. Four design approaches; (Boogaard, 1992), (PIANC, 1997), (CCG, 2001), and (PIANC, 2014) for determining the navigable channel widths through river straight segments and extra widths through meanders were used. Results revealed that approaches (CCG, 2001) and (PIANC, 2014) gave safest channel widths for one-way and two-way straight channels respectively. Also, in sharp meanders, the extra width value given by (CCG, 2001) was preferred, while in normal meanders, the extra width value by (PIANC, 2014) was preferred. Finally, (CCG, 2001) and (PIANC, 2014) were strongly recommended to be applied in design because they provide the highest safety in both straight and meandering river segments compared with other design approaches developed so far.
\end{abstract}

Keywords: Navigable Channels; Waterways; Navigation Design Methods; Egyptian Locks; River Meanders

\section{Introduction}

Waterways are the cheapest mode of transport. They need no construction or maintenance cost as compared with roads and highways (Studyrankers-online) [1]. They are represented by rivers, lakes, seas, and oceans. They can be used for trans-boundary trade between riparian countries. Bulky and heavy materials are usually transported by them. Also, they help to stimulate local and regional economies by acting as a catalyst for urban and rural regeneration and inward investment (British Waterways) [2]. Moreover, they are essential to the tourism industry as cruises in open areas and natural scenery are most favored by tourists.

Inland Waterways were classified into three main types according to (Thoresen, 1988) [3] and as shown in Fig. 1. They are either an open (unrestricted) channel or a confined (restricted) channel or a canal. An unrestricted channel is a relatively large body of water whose bed level is low enough to provide a sufficient flow depth that ensures unobstructed navigation traffic round the year and requires no bed dredging. A river cross-section may be classified as an unrestricted channel if it is wider than eight times the ship beam (width). As for the restricted channel, it is a channel with an underwater trench or a partially dredged channel in shallow water areas. The trench acts as a canal by containing

Received:29 March 2021, Accepted:28 April , 2021 and influencing the flow around the ship. The wide overbank allows the flow to act as if the ship is in an unrestricted channel. In this case, the side slopes of the dredged zone depend on the classification of bed materials. It is obvious that the restricted channel follows the bed configuration of the waterway and is always found at the lowest bed levels. As for the canal, it is a man-made channel that is entirely constructed by excavation. It is a special case of the restricted channel with a trench height higher than the available water surface. Therefore, the canal dimensions along the whole stretch are mostly the same. The design of canal side slopes depends on the type and classification of bed materials. The side slopes are maintained and protected using molded rocks or reinforced concrete.

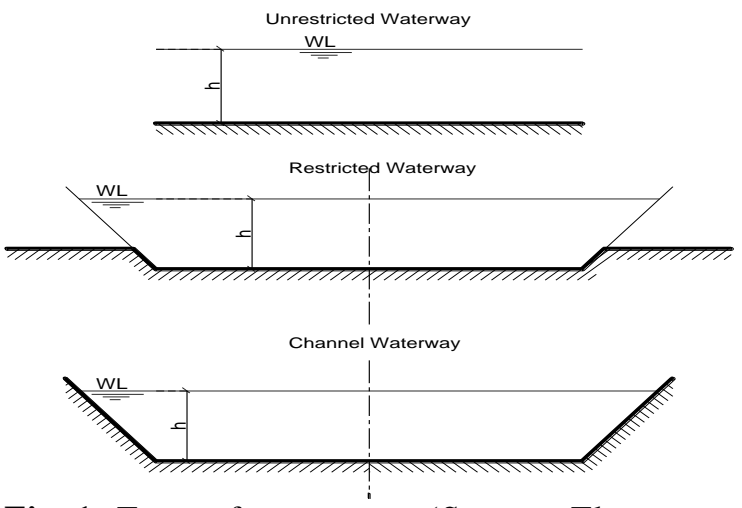

Fig. 1. Types of waterways (Source: Thoresen, redrawn by Authors) 
However, in order to use the waterways for transport, navigable channels have to be constructed along them to secure and guide the transportation traffic. These channels are planned and designed to accommodate the traffic expected to navigate through. The channel width should be proportional to the dimensions of the largest ship expected to pass. Also, the channel should be at least two-way to allow traffic in two directions (up/downstream) simultaneously.

Waterways, especially the long ones, usually consist of a combination of segments/stretches having different cross sections which may be classified as one of the three types mentioned (PIANC, 1997). This is because one side of the waterway may look like unrestricted and the other like restricted with sidewalls. However, one should think of just one type when planning and designing a navigable channel along the waterway. An unrestricted waterway can be formed from a restricted channel if the width is large enough and/or side slopes are gentle enough. Most empirical formulas of the Permanent International Association of Navigation Congresses "PIANC" are based on ships sailing presumably along the centerline of asymmetrical channel. Therefore, the designer has to use the engineering judgment when selecting the most appropriate design formulas.

Regarding the inland traffic intensity (density), there are three different cases; low, medium and high. Accordingly, three corresponding crosssections of different regular dimensions could be defined respectively. When the traffic density is low, a channel with a cross-section of one single traffic lane is implemented to allow the passage of only one loaded design ship at a time. This type is used in short waterways and under special conditions. In case of medium density, a channel with a cross-section of two traffic lanes is constructed to allow two loaded design ships to pass in opposite directions. The channel cross section also allows an unloaded design ship to overtake a loaded one with high caution. If the traffic density is high, a channel with a three way traffic cross section is established to allow two loaded design ships to meet at normal speed and one loaded ship can be overtaken by a third ship with caution. This case is seldom to occur and is applied only when the matter is unavoidable.

Regarding the inland waterways in Egypt which are represented by the River Nile and its branches, there are navigable channels already planned, designed and implemented through them to serve the domestic cargo transportation and tourism. The channel is mainly designed as a two-way route. It is 100 and $40 \mathrm{~m}$ wide along the river main waterway and branches respectively. Vessels of $100 \mathrm{~m}$ length and $15 \mathrm{~m}$ width are only allowed through the main waterway, whereas vessels of 51 $\mathrm{m}$ length and $7.5 \mathrm{~m}$ width are allowed through both of the main waterway and branches.

\section{Objective}

This paper aims to upgrade the navigable channels already established along the River Nile waterways within Egypt to satisfy the inland river transportation requirements. These channels are to be re-designed for ensuring safe ship traffic throughout both river straight segments and meanders and achieving convenient navigability of floating hotels, container ships and twin-ship barge units. Also, the paper aims to identify the most suitable and safest design approach developed so far. On the other hand, it should be noted that the navigable channels will be upgraded in terms of width only. As for the other design parameters such as the ship draft, river depths, navigational route plan, lock widths, and flow releases downstream barrages, they have to be already satisfied according to the current recommendations of the Egyptian River Transport Authority (RTA) as follows:

- The maximum ship draft shouldn't exceed 1.80 $\mathrm{m}$;

- The minimum river depth within the navigable channel shouldn't be less than $2.30 \mathrm{~m}$;

- The navigation vents at bridges should comply with the RTA recommendations;

- The navigational routes should be planned such that they avoid, as much as possible, the riverbed areas of navigational bottlenecks that need dredging and funds;

- The flow discharges released downstream the barrages should be enough to provide the water depths needed;

- The available locks constructed at the existing barrages should have widths sufficient to accommodate the vessels passing through;

- In minimum discharge periods, minimum water levels downstream locks should provide the minimum navigational depths required (2.30) $\mathrm{m}$. Otherwise, ship cargo should be reduced or relieved to decrease the draft;

- Water surface inside the locks should be maintained at least $2.30 \mathrm{~m}$ above the floor levels.

\section{Materials and Methods}

\subsection{Waterways under Study}


The navigation traffic within Egypt has been mainly concentrated along the River Nile main waterway which extends for about $950 \mathrm{~km}$ between Old Aswan Dam "OAD" in Aswan and Delta barrages north of Cairo as shown in Fig. 2a. It has a waterway width ranging between 300 to $1000 \mathrm{~m}$. Also, there are other three important waterways (river branches) that are used regularly for river intensive cargo transportation through the Delta Region north of Egypt. They are Damietta branch, El-Rayah El-Behery, and El-Nubaria canal as shown in Fig. 2b. Damietta branch is about $244 \mathrm{~km}$ long with a waterway width ranging between 250 and $500 \mathrm{~m}$. It starts at Delta Barrages and ends at the open sea port at Damietta on the Mediterranean Sea. As for ElRayah El-Behery, it extends for about $139 \mathrm{~km}$ from Delta Barrages until it meets Kafr AlDawar-Motobas canal at km (15.10) downstream its entrance at Rosetta branch at $\mathrm{km}$ (187) downstream Delta Barrages. it has a waterway width ranging between 50 and $75 \mathrm{~m}$. As for El-Nubaria canal, it branches off ElRayah El-Behery at km (82.20) downstream Delta Barrages and extends for $120 \mathrm{~km}$ long until the Mediterranean Sea at Lake Marriott. Its waterway has a width ranging between 30 and $55 \mathrm{~m}$ (Samuel) [4]. Within all these waterways, there are locks of widths equal to $16 \mathrm{~m}$ or more that can accommodate ships of widths reaching $15 \mathrm{~m}$. So, there are no problems in improving the present navigable channels existing through these waterways to meet the new traffic requirements. Table 1 shows a list of these locks. The bed levels of some of these locks compared with their downstream minimum water levels can provide enough navigational depths, while others don't. Therefore, when the downstream water depth is not sufficient for any reason (for instance, winter closure or water rationalization), ships should reduce their cargoes to decrease their drafts lest they should get grounded. In extreme cases of water unavailability, river transport should completely stop or pause until water is back again.

On the other hand, the navigable channels along these waterways currently suffer problems that hinder and/or delay the navigation traffic. Such problems comprise navigation bottlenecks, sharp meandering and channel narrowness.

The major problem that disturbs the navigable channels along the four waterways altogether is the navigation bottlenecks that take place and grow over time due to the bed aggradation/degradation processes induced by the navigation traffic and the external interventions. These bottlenecks always require repeated dredging works and consequently large financial budgets.

As for meandering, Damietta branch is characterized by being largely sinuous and having more than 50 meanders along its length (Sadek) [5]. The bends always cause abrupt transition areas especially in waterway width between the curved and straight segments (Herbich) [6]. This transition causes changes in the flow patterns which induce unbalanced hydrodynamic forces that may act on the ship dangerously while it enters the waterway at the bend. Therefore, the transition between straight and curved segments should be as gradual as possible to lessen or absorb the flow changes impacts.

As for narrowness, the existing navigable channel is mainly designed as a two-way route. It is 100 and $40 \mathrm{~m}$ wide along the river main waterway and three branches respectively. Vessels of $100 \mathrm{~m}$ length and $15 \mathrm{~m}$ width are only allowed through the main waterway but not through the branches, whereas vessels of $51 \mathrm{~m}$ length and $7.5 \mathrm{~m}$ width are allowed through both of the main waterway and branches. However, on considering the modern navigation requirements, especially project VICMED, the problem of the two-way channel narrow width (40 m) will influence the river transport largely, especially along the three branches. Therefore, the channel upgrade is deemed unavoidable.

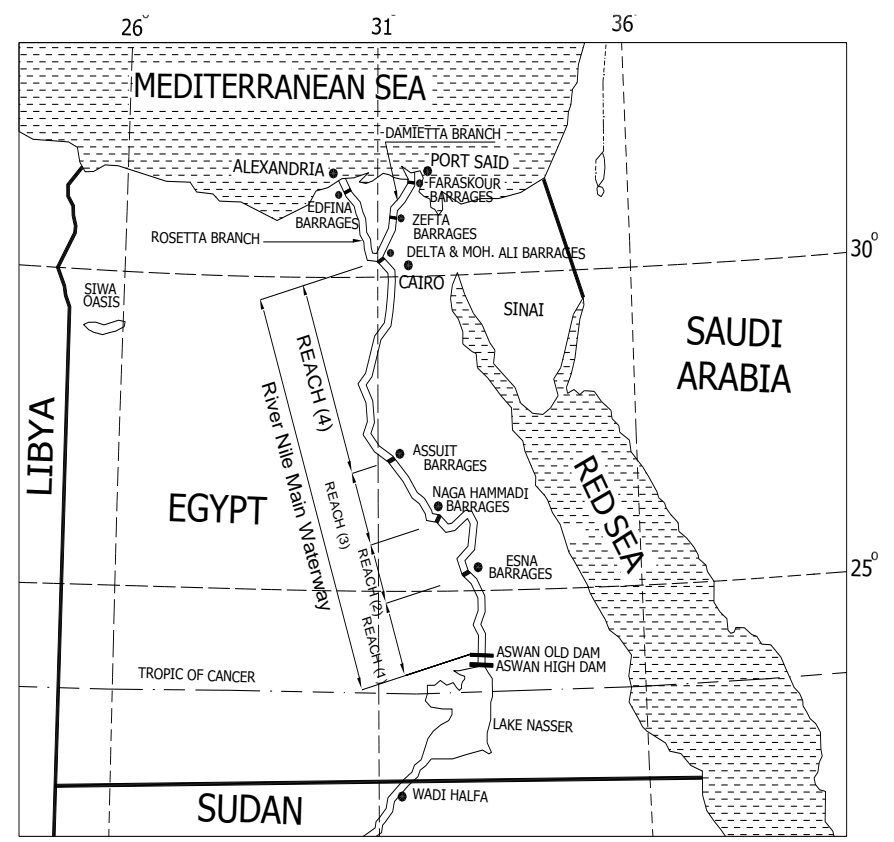

Fig. 2a. Egypt map showing the River Nile Main Waterway and Main Barrages. 


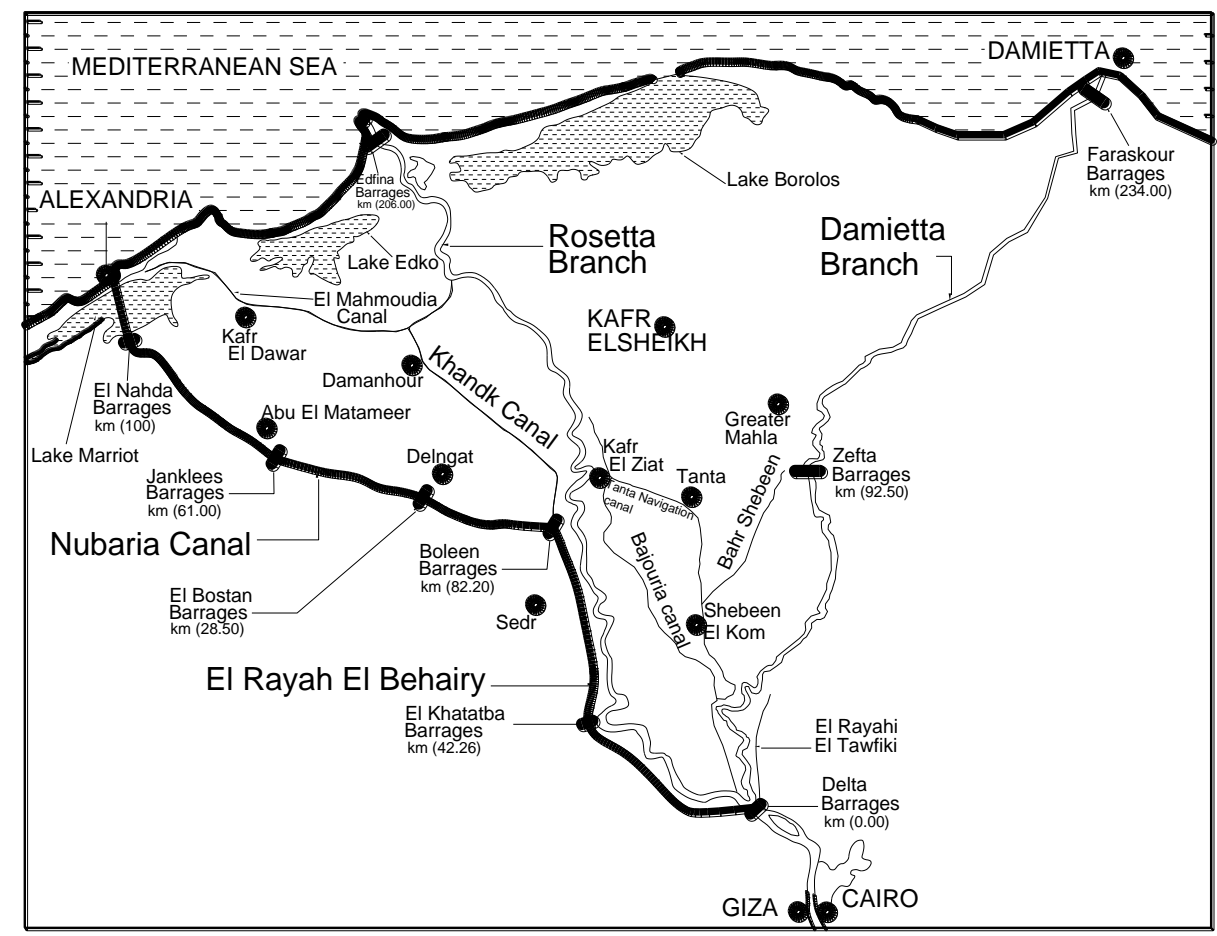

Fig. 2b. Damietta branch, El-Rayah El-Behery and El-Nubaria Canal and the locations of barrages along them

Table 1

Data of Locks along River Nile Main waterway, Damietta branch, El Rayah El Behairy and Nubaria Canal

\begin{tabular}{|c|c|c|c|c|c|c|c|c|c|}
\hline $\begin{array}{l}\text { River Nile } \\
\text { Waterway }\end{array}$ & Lock name & $\begin{array}{l}\text { Reach } \\
\text { name }\end{array}$ & $\begin{array}{c}\mathrm{Km} \mathrm{D} / \mathrm{S} \\
\mathbf{O A D}\end{array}$ & $\begin{array}{l}\text { Length } \\
\text { (m) }\end{array}$ & $\begin{array}{c}\text { Width } \\
\text { (m) }\end{array}$ & $\begin{array}{c}\text { Floor } \\
\text { level (a } \\
\text { msl) }\end{array}$ & $\begin{array}{c}\text { D/S } \\
\text { Mean } \\
\text { Min WL }\end{array}$ & $\begin{array}{c}\text { Available } \\
\text { Navigational } \\
\text { Depth (m) } \\
\end{array}$ & $\begin{array}{l}\text { Navigation } \\
\text { Status }\end{array}$ \\
\hline Main & Esna (old) & First & 167.0 & 80 & 16 & 70.30 & 72.03 & & \\
\hline Main & Esna (new) & First & 169.0 & 116 & 17 & 66.60 & 72.03 & 5.43 & $\mathrm{OK}$ \\
\hline Main & $\begin{array}{l}\text { Naga Hammadi } \\
\text { (old) }\end{array}$ & Second & 359.5 & 80 & 16 & 58.00 & 58.87 & & \\
\hline Main & $\begin{array}{l}\text { Naga } \\
\text { (new) }\end{array}$ & Second & 361.0 & 177 & 17 & 54.88 & 58.87 & 3.99 & OK \\
\hline Main & Assuit (old) & Third & 546.0 & 80 & 16 & 43.25 & 44.62 & & \\
\hline Main & Assuit (new) & Third & 547.0 & 117 & 17 & 38.00 & 44.62 & 6.62 & $\mathrm{OK}$ \\
\hline Main & Delta (old) & Fourth & 953.0 & 80 & 12 & 4.00 & 13.03 & & \\
\hline \multirow[t]{2}{*}{ Main } & Delta (new) & Fourth & 953.5 & 100 & 12 & 4.00 & 13.03 & 9.03 & $\mathrm{OK}$ \\
\hline & & $\begin{array}{c}\text { Branch } \\
\text { name }\end{array}$ & $\begin{array}{c}\text { Km D/S } \\
\text { Delta }\end{array}$ & & & & & & \\
\hline Branch & $\begin{array}{l}\text { Delta Barrages } \\
\text { (Entrance) }\end{array}$ & Damietta & 0.00 & 80 & 12 & 4.00 & 13.03 & & \\
\hline Branch & $\begin{array}{l}\text { Delta Barrages } \\
\text { (Entrance) }\end{array}$ & Damietta & 0.00 & 100 & 12 & 4.00 & 13.03 & 9.03 & $\mathrm{OK}$ \\
\hline Branch & Zefta (old) & Damietta & 92.5 & 80 & 12 & 3.50 & 3.80 & & \\
\hline Branch & Zefta (new) & Damietta & 92.5 & 150 & 17 & 1.50 & 3.80 & 2.30 & $\begin{array}{l}\text { Not OK } \\
\text { (Need cargo } \\
\text { reduction) }\end{array}$ \\
\hline \multirow[t]{2}{*}{ Branch } & Faraskour & Damietta & 234.0 & 80 & 12 & -5.00 & 0 & 5.00 & $\mathrm{OK}$ \\
\hline & & $\begin{array}{c}\text { Rayah } \\
\text { name }\end{array}$ & $\begin{array}{c}\text { Km D/S } \\
\text { Inlet }\end{array}$ & & & & & & \\
\hline Rayah & Entrance (old) & El Behairy & 0.00 & 55 & 12 & 10.5 & & & \\
\hline Rayah & Entrance (new) & El Behairy & 0.00 & 116 & 16 & 7.00 & 9.64 & 2.64 & $\mathrm{OK}$ \\
\hline Rayah & Khatatba (old) & El Behairy & 42.26 & 80 & 12 & 7.08 & ---- & & \\
\hline \multirow[t]{2}{*}{ Rayah } & Khatatba (new) & El Behairy & 42.26 & 116 & 16 & 5.00 & 8.25 & 3.25 & $\mathrm{OK}$ \\
\hline & & $\begin{array}{l}\text { Canal } \\
\text { name }\end{array}$ & $\begin{array}{c}\mathbf{K m} \mathbf{D} / \mathbf{S} \\
\text { Inlet }\end{array}$ & & & & & & \\
\hline Canal & Entrance (Boleen) & Nubaria & 0.00 & 116 & 16 & 4.70 & 7.90 & 3.20 & $\mathrm{OK}$ \\
\hline Canal & Bostan & Nubaria & 28.50 & 116 & 16 & 3.25 & 6.47 & 3.22 & OK \\
\hline Canal & Janklees & Nubaria & 61.00 & 116 & 16 & 2.24 & 4.16 & 1.92 & $\begin{array}{l}\text { Not OK } \\
\text { (Need cargo } \\
\text { reduction) }\end{array}$ \\
\hline Canal & El Nahda & Nubaria & 100.0 & 116 & 16 & -5.50 & 0.00 & 5.50 & OK \\
\hline
\end{tabular}




\subsection{Determination of the Representative Design Ship}

The representative design ship dimensions have to be specified carefully as they govern the design of the navigable channel dimensions. The ship constitutes the greatest incident risk in the navigable channel. The choice of such a ship was subject to a statistical analysis of the available data of all types of the used cargo transportation and tourist units (NRI) [7]. The physical dimensions of all the registered floating hotels along the River Nile main waterway in Egypt were analyzed and classified. Results revealed a representative floating hotel of $75 \mathrm{~m}$ length, 15 $\mathrm{m}$ width and $1.8 \mathrm{~m}$ draft (Fahmy) [8].

For the other three river waterways (branches), dimensions of all cargo transportation units sailing through them were also analyzed. This took place during a development project proposed by the Egyptian
River Transport Authority "RTA" in 2006 to increase cargo transportation through Damietta branch.

Three design ships were assigned during that project; one single propelled unit of $100 \mathrm{~m}$ long and $7.5 \mathrm{~m}$ width; the twin-ship barge unit of pusher barge and pushed dump barge of $100 \mathrm{~m}$ total length and $7.5 \mathrm{~m}$ width and the container ship unit of $100 \mathrm{~m}$ long and $11.6 \mathrm{~m}$ width. Also, the project proposed to upgrade the navigable channels in straight segments and meanders to cope with the new ship dimensions and ensure safe navigation traffic. However, the project has not been implemented so far. Table 2 below shows the proposed future dimensions of the representative design ship, under keel clearance, and the water flow depth along the river main waterway and the three branches compared with those which are currently in use.

Table 2

Comparison of Principal Design Parameters; present and future

\begin{tabular}{|c|c|c|c|c|c|c|}
\hline \multirow{3}{*}{ No. } & & & \multicolumn{4}{|c|}{ Design values (m) } \\
\hline & \multirow{2}{*}{\multicolumn{2}{|c|}{ Design parameters }} & \multicolumn{2}{|c|}{ The River Nile main waterway } & \multicolumn{2}{|c|}{ The three branches } \\
\hline & & & Current & Future & Current & Future \\
\hline 1 & Design ship length & (Ls) & 100 & 100 & 51 & 100 \\
\hline 2 & Design ship beam & (Bs) & 15 & 15 & 7.5 & 11.6 \\
\hline 3 & Design ship draft & (Ts) & 1.8 & 1.8 & 1.8 & 1.8 \\
\hline 4 & Under keel clearan & $\left(\mathrm{C}_{\mathrm{k}}\right)$ & 0.5 & 0.5 & 0.5 & 0.5 \\
\hline 5 & Req. Water flow de & $(\mathrm{h})$ & 2.3 & 2.3 & 2.3 & 2.3 \\
\hline
\end{tabular}

\subsection{Previous Studies}

El Sersawy [9] conducted a research study that came up with a new design for the widths of the navigable channels along the River Nile waterways that accommodated the $1^{\text {st }}$ class cargo transportation traffic. In that study, four design methods were used. Two were empirically developed to determine the navigable channel width along the waterway straight segments, while the other two were applied on both straight and curved segments. The four waterways defined earlier above (the River Nile main waterway, Damietta branch, El-Rayah El-Behery, and ElNubaria canal) were taken as case studies. The design ships selected to design the navigable channel widths were $100 \mathrm{~m}$ long and $15 \mathrm{~m}$ wide through the main waterway and $51 \mathrm{~m}$ long and 7.5 $\mathrm{m}$ wide through the other branches. However, the selected design ship for the 3 river branches at the time is different from that is currently required.

On the other hand, as Damietta branch is a typically sinuous meandering waterway, the navigable channel through such bends must be designed to ensure safe traffic in terms of adequate water depth and maneuvering space. The basic layout and alignment of the channel is to be primarily decided based on the waterway bed morphology. It is generally accepted that an additional channel width is necessary through a bend to account for the added difficulties of maneuvering and the broader swept path of the ship. This is because ships cannot make instantaneous changes in direction, but follow an arc. Therefore, the design of channels at bends must show the track that ships will actually follow. For these reasons, navigable tracks along the bends of all natural and canalized waterways are much wider than those in straight directions. Whereas the vessels in straight stretches/segments only wriggle with a maximum horizontal rotation angle of $\pm 3^{\circ}$, the vessels in the river bend in the downstream direction drift with a horizontal rotation angle of up to $20^{\circ}$ (Prsic) [10]. However, 
vessel drifting would be less expressed in the upstream direction because the rudder obeys better and therefore the upstream track would be narrower. Fig. 3 shows the way described by
(Prsic) [10] when a vessel sails through bend channel tracks (lanes) up and downstream.

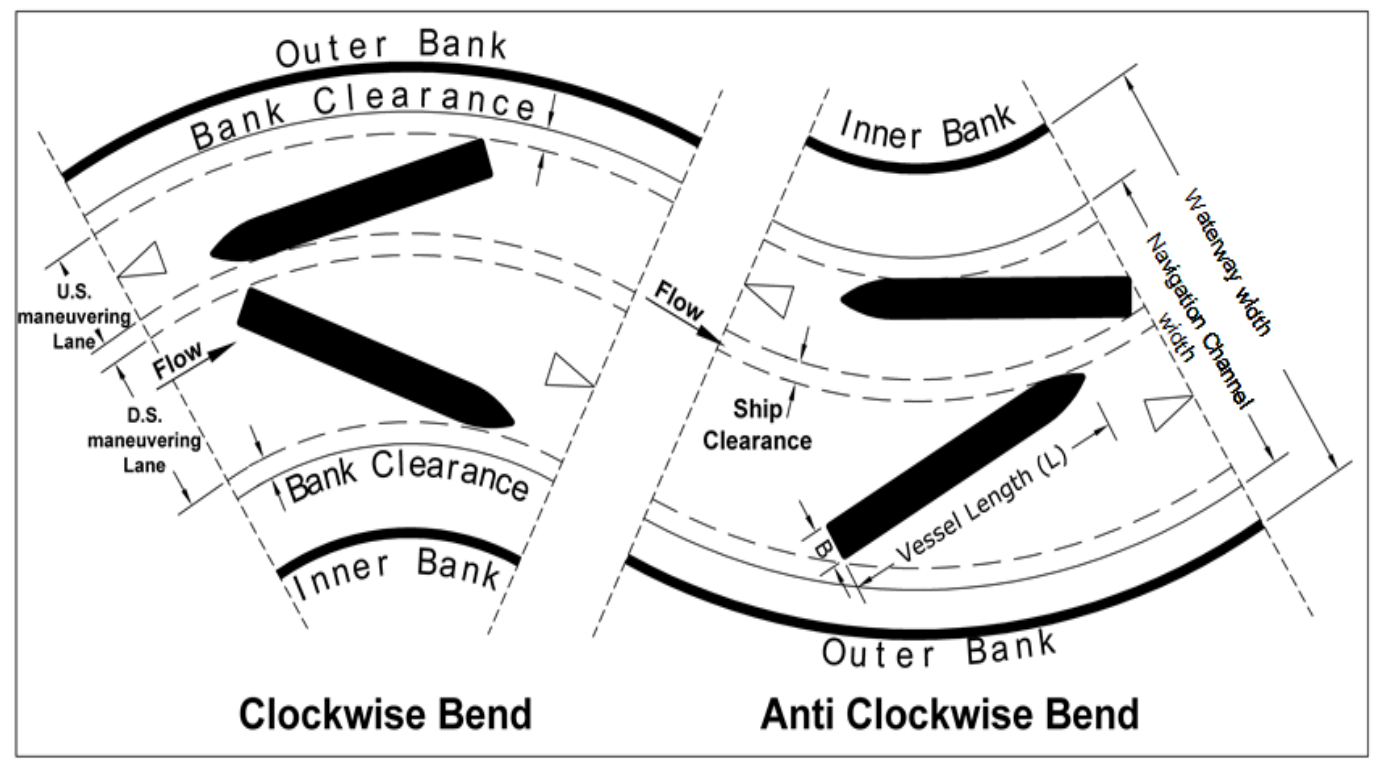

Fig. 3. A definition sketch for vessel passage through bend tracks (Prsic) [10].

\subsection{Navigable Channel Design Methods}

Until recently, various guidelines and recommendations for design of navigable channels have been set to improve navigation and minimize construction and maintenance costs. This is due to the fact that the design of a waterway channel is highly site specific. So, it is too difficult to derive or apply a set of general guidelines without having strong practical background or expertise. There are three design methods that are widely used worldwide namely; guideline, empirical and common design. Each method includes different alternatives and/or trials that can help achieve the safest and most efficient channel width. However, both the guideline and empirical methods are only applicable for straight waterway channels. They don't consider the meander effect. Therefore, they will be excluded from discussion here. On the other hand, the U.S. Army Corps of Engineers (USACE) [11] revealed that for two-way traffic, it is essential that traffic bound downstream should move along the concave (outer) river bank of the bend and that bound upstream should move along the convex (inner) river bank. Also, the minimum clearance between channel limit lines should be 20 feet $(6.1 \mathrm{~m})$ and the clearance between vessels should be 50 feet $(15.2 \mathrm{~m})$.

\subsubsection{Common Design Methods (for straight river segments)}

The common design methods can be applied for straight and curved waterways altogether. They are four and can be discussed as follows:

\subsubsection{Boogaard Method}

This method was published by Boogaard [12]. It is applicable for still water. The necessary modifications for the effect of cross winds, channel bends and flow velocity are considered. The final designed waterway channel width is expressed as a multiple of the representative design ship (width) beam. As shown in Fig. 4, a trapezoidal section is selected as a suitable shape. In this figure, $h$ is the water depth $(m), T_{s}$ is the ship draught $(m), b_{t}$ is the channel width at keel level $(\mathrm{m})$, Bs is the ship width $(m), A_{m}$ is the mid-ship area $\left(m^{2}\right)$, and $A_{c}$ is the wetted cross section area $\left(\mathrm{m}^{2}\right)$. 


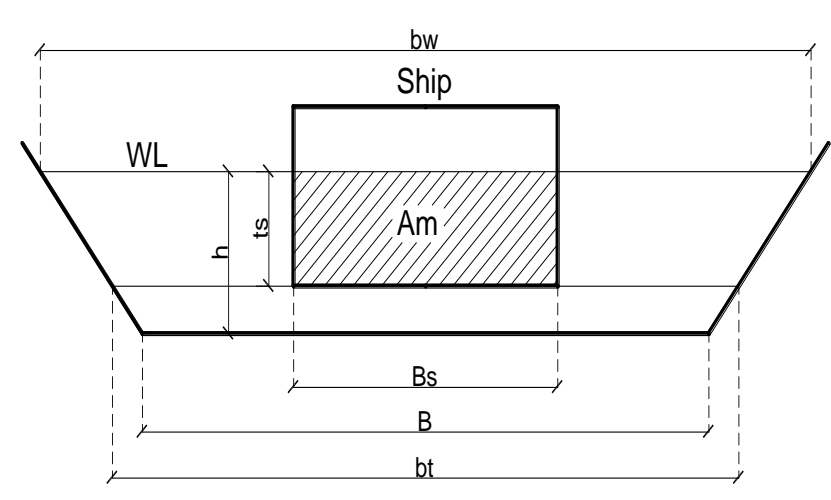

Fig. 4. Elements of a Waterway Cross Section

This approach reveals that the first step for channel design is to determine the required width of the maneuvering lane. This was defined as the channel within which the ship may easily maneuver without encroaching on the safe bank clearance or without approaching another ship too closely. It is likely that a lane width must be large enough to secure safe navigation. This method takes the land width as 2Bs. Applying the necessary criteria to guarantee safe and high degree of maneuverability, Table $\mathbf{3}$ was produced as guideline for waterway channel design. Knowing the representative ship beam (Bs) and draft $T_{s}$, each of the water flow depth (h) and the navigation channel width of still water at keel level $\left(b_{t}\right)$ can be computed.

Table 3

Still water guidelines for channel design

\begin{tabular}{cccc}
\hline \multirow{2}{*}{ Criterion } & \multicolumn{3}{c}{ Guidelines for channel design } \\
\cline { 2 - 4 } & One-way & Two-way & Three-way \\
\hline $\mathrm{h} / \mathrm{T}_{\mathrm{s}}$ & 1.3 & 1.3 & 1.4 \\
\hline $\mathrm{b}_{\mathrm{t}} / \mathrm{Bs}$ & 2.0 & 3.0 & 4.0 \\
\hline $\mathrm{V}_{\max }$ & $(5-6) \mathrm{Km} / \mathrm{h}$ & $(7-8) \mathrm{Km} / \mathrm{h}$ & $(8.5-10.0) \mathrm{Km} / \mathrm{h}$ \\
\hline
\end{tabular}

There are three different increments for the calculated channel width that can be determined as follows:

- For the case of unloaded ships, the navigation channel width Bs should be increased to cope with the effect of cross winds. Measurements on some canals indicated that the maximum increment equals the ship beam (Bs);

- The channel width should have an increase to compensate for the bend effect. This will be covered over the following sections; and

- The channel width should be increased to neutralize the flow current effects. This

\subsubsection{PIANC Methods}

The design methods of PIANC [13] and [14] are based on the development of two main equations that calculate the navigable channel width in either of the single or two way channels as a multiple of the beam of the design ship. The radius of curvature of a bend is expressed as a multiple of its length, while the channel depth is related to the ship draft. Considering each of the two navigable channel types, dimensions and increase can be estimated by field experience. It depends on the following four conditions:

1. If the mean flow velocity $V_{W}$ is less than or equal $0.5 \mathrm{~m} / \mathrm{s}$, no extra increase is recommended.

2. If $0.5 \mathrm{~m} / \mathrm{s}<\mathrm{V}_{\mathrm{W}}<1.5 \mathrm{~m} / \mathrm{s}$ for meeting maneuvers, the navigable channel width should be increased up to $0.2 \mathrm{Bs}$

3. If $0.5 \mathrm{~m} / \mathrm{s}<\mathrm{V}_{\mathrm{W}}<1.5 \mathrm{~m} / \mathrm{s}$ for overtaking maneuvers, the navigable channel width should be increased up to $0.5 \mathrm{Bs}$

4. If $\mathrm{V}_{\mathrm{W}}>1.5 \mathrm{~m} / \mathrm{s}$, the increase in channel width should be determined by theoretical studies and/or full scale model tests.

maneuvering conditions of the representative design ship, the preliminary design of the navigable channel can be determined. The concept deals with the width and depth of straight navigation sections and gives guidelines to compensate for the effects resulting from bends. The navigable channel width elements in a straight segment/stretch are shown in Fig. 5. They can be evaluated for one and two-way channels using Eqs. 1 and 2: 


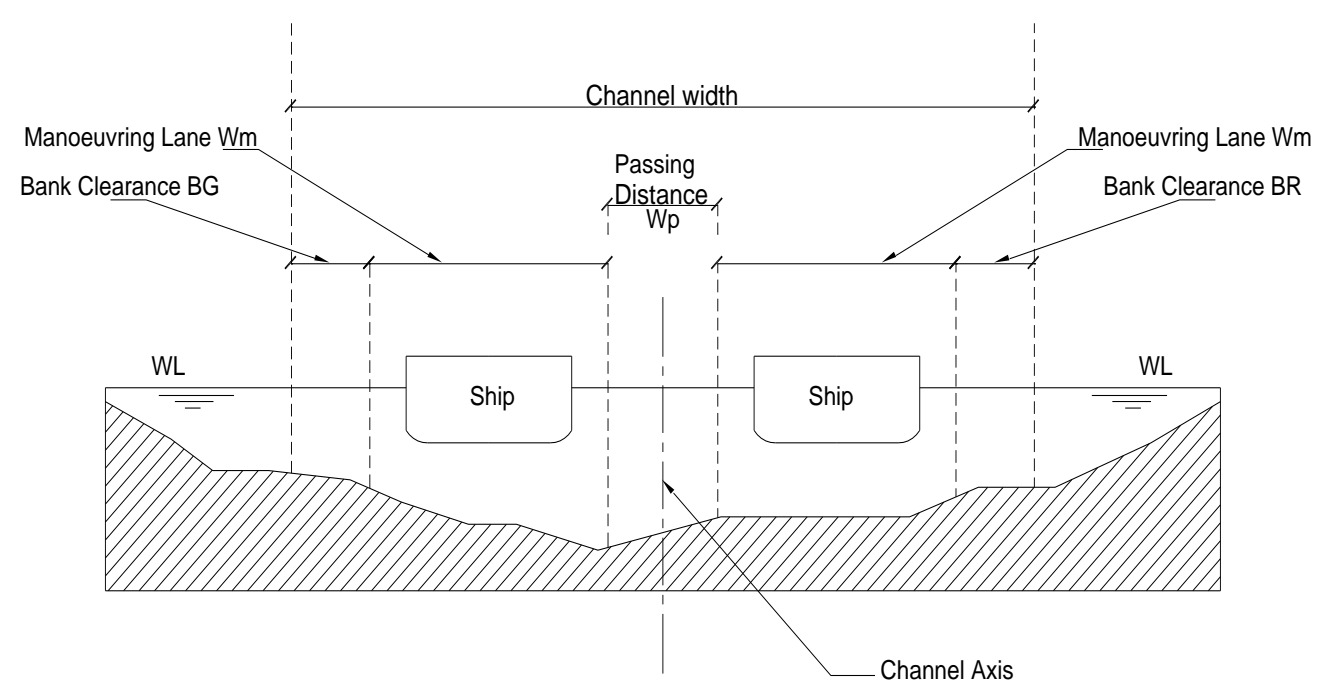

Fig.5. Elements of a navigable channel width for two-way traffic

$$
\begin{aligned}
& W=W_{B M}+\sum_{i=1}^{n} W_{i}+W_{B R}+W_{B G} \\
& W=2 W_{B M}+2 \sum_{i=1}^{n} W_{i}+W_{B R}+W_{B G}+\sum W_{P}
\end{aligned}
$$

Where $\mathrm{W}$ is the final navigable channel width; $\mathrm{W}_{\mathrm{BM}}$ is the required channel width for maneuvering; Wi are additional channel widths due to ship speed and wave; $\mathrm{W}_{\mathrm{BR}}$ and $\mathrm{W}_{\mathrm{BG}}$ are the bank clearance on the right and left sides of the

Table 4

\begin{tabular}{|c|c|c|c|}
\hline \multicolumn{4}{|c|}{ Basic Maneuvering Lane } \\
\hline $\begin{array}{l}\text { Ship } \\
\text { Maneuverability }\end{array}$ & Good & Moderate & Poor \\
\hline $\begin{array}{l}\text { Basic Maneuvering } \\
\text { Lane, WBM }\end{array}$ & $1.3 \mathrm{Bs}$ & $1.5 \mathrm{Bs}$ & $1.8 \mathrm{Bs}$ \\
\hline \multicolumn{4}{|c|}{ Width of Passing Distance for Two-Way Traffic } \\
\hline $\begin{array}{l}\text { Width for passing } \\
\text { distance }\left(\mathrm{W}_{\mathrm{p}}\right)\end{array}$ & $\begin{array}{c}\text { Vessel } \\
\text { Speed and } \\
\text { Traffic } \\
\text { density }\end{array}$ & $\begin{array}{l}\text { PIANC } \\
1997\end{array}$ & $\begin{array}{c}\text { PIANC } \\
2014\end{array}$ \\
\hline \multirow{3}{*}{ Vessel speed (knots) } & $\begin{array}{c}- \text { fast }> \\
12\end{array}$ & - & $1.8 \mathrm{Bs}$ \\
\hline & $\begin{array}{c}- \\
\text { moderate } \\
>8-12\end{array}$ & $1.4 \mathrm{Bs}$ & $1.4 \mathrm{Bs}$ \\
\hline & $\begin{array}{c}- \text { slow } 5- \\
8\end{array}$ & $1.0 \mathrm{Bs}$ & $1.0 \mathrm{Bs}$ \\
\hline \multirow{3}{*}{$\begin{array}{l}\text { Encounter traffic } \\
\text { density }\end{array}$} & - light & - & - \\
\hline & $\begin{array}{c}- \\
\text { moderate }\end{array}$ & $0.2 \mathrm{Bs}$ & $0.2 \mathrm{Bs}$ \\
\hline & - heavy & $0.4 \mathrm{Bs}$ & $0.4 \mathrm{Bs}$ \\
\hline \multicolumn{4}{|c|}{ Additional Width for Bank Clearance } \\
\hline $\begin{array}{l}\text { Width Clearance } \\
\left(\mathrm{W}_{\mathrm{BR}} \text { or } \mathrm{W}_{\mathrm{BG}}\right)\end{array}$ & $\begin{array}{l}\text { Vessel } \\
\text { speed }\end{array}$ & $\begin{array}{c}\text { PIANC } \\
1997\end{array}$ & $\begin{array}{c}\text { PIANC } \\
2014\end{array}$ \\
\hline
\end{tabular}

Design elements for a navigable channel navigable channel; $\mathrm{W}_{\mathrm{p}}$ is the passing distance between ships. In order to evaluate the different elements of the two equations, the additional values for channel width (Wi) is defined in separate tables. In this case, PIANC [13] and [14] provided a set of look-up tables which include additional width allowance on the basic maneuvering lane width, which takes into account the vessel speed drift due to wind, drift due to current wave effects, aids to navigation visibility, seabed material channel depth and cargo hazard level. While the other design elements are given in Table 4 as a multiple of the design ship beam.

\begin{tabular}{lccc}
\hline \multirow{2}{*}{$\begin{array}{l}\text { Sloping channel } \\
\text { edges and shoals }\end{array}$} & Fast & - & $0.7 \mathrm{Bs}$ \\
\cline { 2 - 4 } & Moderate & $0.5 \mathrm{Bs}$ & $0.5 \mathrm{Bs}$ \\
\cline { 2 - 4 } & Slow & $0.3 \mathrm{Bs}$ & $0.3 \mathrm{Bs}$ \\
\hline $\begin{array}{l}\text { Steep and hard } \\
\text { embankments, } \\
\text { structures }\end{array}$ & Fast & - & $1.3 \mathrm{Bs}$ \\
\cline { 2 - 4 } & Moderate & $1.0 \mathrm{Bs}$ & $1.0 \mathrm{Bs}$ \\
\cline { 2 - 4 } & Slow & $0.5 \mathrm{Bs}$ & $0.5 \mathrm{Bs}$ \\
\hline
\end{tabular}

\subsubsection{Canadian Method}

This method was developed by the Canadian Coast Guards (CCG) [15] to determine the navigable channel parameters that fulfill efficient maneuverability with no less than minimum safety margins and allowances. The method is based on the operational requirements for ships that can provide the conceptual requirements for safe and efficient navigation. The design procedure for each element of the navigable channel geometry is provided. However, good judgment, experience and common sense are required when they are applied. In this method, the total channel width for two-way traffic refers to the measured horizontal distance from the toe-to-toe side slopes at the design depth. It can be expressed as follows: 

Total Channel Width $=$ Design Width +
Allowances

The design width refers to the summation of width requirements for design ship maneuvering, hydrodynamic interactions between meeting and passing vessels, cross winds and cross currents, counteracting bank suction and navigational aids (including pilots). Also, allowances refer to the additional width increases that compensate for bank slumping, erosion, sediment transport, deposition, and type of bank materials. As for the effect of bottom surface, it is important only in shallow waterways. If the depth is more than 1.5 times the draft of the design ship, no additional width is needed. A guide for all the design parameters is given by CCG [15].

\subsubsection{Common Design Methods (for river meanders)}

\subsubsection{Boogaard Method}

Ships traveling and maneuvering along bends usually undergo severe unbalance and instability due to changes in channel directions. This, in turn, creates moment and hydrodynamic forces that increase steering difficulty of the vessel transiting the bend. Accordingly, the navigable channel width along bends should be greater than that along straight segments/stretches. The common design method by Boogaard [16] recommended an increase in navigable channel width of $\Delta b_{L}$ and $\Delta b_{u}$ due to the bends at the keel level in the cases of loaded and unloaded ships respectively. These values can be computed for the case of two-way traffic as follows:

$$
\Delta \mathbf{b}_{\mathrm{L}}=\left(\mathrm{L}_{\mathrm{s}}\right)^{2} / 2 \mathrm{r}
$$

$$
\Delta \mathbf{b}_{\mathrm{u}}=\left(\mathbf{L}_{\mathrm{s}}\right)^{2} / \mathbf{r}
$$

Where " $\mathrm{r}$ " is the radius of curvature and " $\mathrm{L}_{\mathrm{s}}$ " is the representative ship length.

\subsubsection{USACE Method}

The U.S. Army Corps of Engineers [11] stated that the need for additional width in bends has been known and recognized but little information has been available on the amount required. Therefore, the channel width in bends was estimated as a direct function of the deflection angle of the ship which is depending on many factors and can be computed as follows:

$$
\mathrm{CW}_{2}=\left(\sin \alpha_{\mathrm{u}} \times \mathrm{L}_{1}\right)+\mathrm{Bs}_{1}+\left(\sin \alpha_{\mathrm{d}} \times \mathrm{L}_{2}\right)+\mathrm{Bs}_{2}+
$$$$
\mathbf{2 C}+\mathrm{C}_{\mathrm{t}}
$$

Where $\mathrm{CW}_{2}$ is the channel width required for two-way traffic (in feet), $\alpha_{u}$ and $\alpha_{d}$ are the maximum deflection angles of up and down bound ships respectively (in degrees), L is the ship length (in feet), Bs is the ship width (in feet), $\mathrm{C}$ is the clearance required between the ship and channel limit (boundary) for safe navigation, and $\mathrm{C}_{\mathrm{t}}$ is the minimum clearance required between passing ships for safe two-way navigation. Considering that $\mathrm{C}=\mathrm{W}_{\mathrm{BR}}=\mathrm{W}_{\mathrm{BG}}=0.3 \mathrm{Bs}$ and $\mathrm{C}_{\mathrm{t}}=1.0$ $\mathrm{Bs}$ and $\mathrm{Bs}_{1}=\mathrm{Bs}_{2}=\mathrm{Bs}, \mathrm{L}_{1}=\mathrm{L}_{2}=100 \mathrm{~m}=328.1$ feet and $\alpha_{u}=\alpha_{d}$. Eq. 6 can be re-written as follows:

$\mathrm{CW}_{2}=137.016+656.2 \mathrm{Sin} \alpha$

For example, assume that the maximum deflection angle is 12 degrees, the total channel width required for two-way traffic will be $=$ 273.447 feet $(83.35 \mathrm{~m})$.

\subsubsection{PIANC Methods}

PIANC [13] stated that when sailing through a bend in the navigable channel, the width of the swept path should increase. A bend curvature of " $r$ " more than $10 \mathrm{~L}$ is preferred, but " $r$ " mustn't be less than $5 \mathrm{~L}$. Straight segments of greater than 10 L should link consecutive bends. The extra channel width through the bend should be $\left[\mathrm{L}^{2} / 8 \mathrm{r}\right]$ and the change in channel width should not exceed $10 \mathrm{~m}$ through $100 \mathrm{~m}$.

An extra width through a channel bend was recommended by the CCGs in 2001 to be added to the channel width to account for maneuvering difficulties while transiting through a bend of a radius of curvature less than 6 times the design ship length. This excess depends mainly on the depth/draft ratio $(\mathrm{D} / \mathrm{d})$ and varies from $0.3 \mathrm{Bs}$ at $\mathrm{D} / \mathrm{d}=1.10$ to about $1.6 \mathrm{Bs}$ at $\mathrm{D} / \mathrm{d}=1.50$.

PIANC [14] revealed that an additional waterway channel width " $\Delta \mathrm{W}$ " is necessitated by the increase in the drift angle of the vessel and response time from the instant when the vessel deviates from the straight channel axis. Therefore, the total additional width in a bend " $\Delta \mathrm{W}$ " due to the swept path is equal to the sum of the additional width due to these two factors (vessel drift angle \& response time). The additional width due to the drift angle $\Delta \mathrm{W}_{\mathrm{DA}}$ can be determined by using the simplified formula:

$\Delta \mathbf{W}_{\text {DA }}=\mathbf{L}^{2} / \mathbf{A r}$ 
Where " $\mathrm{r}$ " is the bend radius, " $\mathrm{L} "$ is the overall ship length, and A is a factor depending on the ship type which is equal to 8.0 for normal ships. An additional width $\Delta \mathrm{W}_{\mathrm{RT}}$ is required in bends to compensate for the time delay of the ship-handler in responding to a required alteration of course. In the concept design stage, the following allowance is recommended:

$\Delta \mathrm{W}_{\mathrm{RT}}=\mathbf{0 . 4 B s}$

\subsection{Application of the Design Methods on the Present Study Waterways}

Using the abovementioned design methods, the channel widths were calculated. The methods are separately applied for straight and curved bend segments as follows:

\subsubsection{Through River Straight Segments}

The final results of channel width values for a two-way traffic straight segment were calculated using Boogaard [12]. They are listed in Table 5.

Knowing the dimensions of the representative design ship, the recommended design Eq. 2 for a two-way traffic channel by PIANC [13] and [14] were applied according to the specified Table 5. The navigation and flow conditions selected to calculate various design parameters are listed in Table 6, while Table 7 lists the final calculation results of the designed channel widths for straight segments.

Table 5

Estimated Channel Widths by (Boogaard, 1992)

\begin{tabular}{clcc}
\hline \multirow{2}{*}{ No. } & \multirow{2}{*}{ Waterway channel parameters } & \multicolumn{2}{c}{ Design parameters $(\mathrm{m})$} \\
\cline { 3 - 4 } & Value of bt/Bs in Table $(4)$ & Main waterway \& Damietta & Other two branches \\
\hline 1 & Channel width in still water $\left(\mathrm{b}_{\mathrm{t}}\right)$ & 3.0 & 2.0 \\
\hline 2 & Width increase due to wind $(\mathrm{Bs})$ & $3.0 \mathrm{Bs}$ & $3.0 \mathrm{Bs}$ \\
\hline 3 & Mean current velocity $\left(\mathrm{V}_{\mathrm{W}}\right)$ & $1.0 \mathrm{Bs}$ & $1.0 \mathrm{Bs}$ \\
\hline 4 & Increase due to flow current $\left(\mathrm{B}_{\mathrm{v}}\right)$ & $\mathrm{V}_{\mathrm{W}}>0.5(\mathrm{~m} / \mathrm{s})$ & $\mathrm{V}_{\mathrm{W}}>0.5(\mathrm{~m} / \mathrm{s})$ \\
\hline 5 & Two-way channel width & $0.5 \mathrm{Bs}$ & $0.5 \mathrm{Bs}$ \\
\hline
\end{tabular}

Table 6

Design Parameters Calculations by PIANC (in meters)

\begin{tabular}{|c|c|c|c|c|c|c|}
\hline \multirow[b]{2}{*}{ The Design Element } & \multicolumn{3}{|c|}{ PIANC 1997} & \multicolumn{3}{|c|}{ PIANC 2014} \\
\hline & $\begin{array}{c}\text { Main } \\
\text { waterway }\end{array}$ & $\begin{array}{c}\text { Damietta } \\
\text { branch }\end{array}$ & $\begin{array}{c}\text { Behairy\& } \\
\text { Nubaria }\end{array}$ & Main waterway & $\begin{array}{c}\text { Damietta } \\
\text { branch }\end{array}$ & $\begin{array}{c}\text { Behairy\& } \\
\text { Nubaria } \\
\end{array}$ \\
\hline Ship maneuverability $\left\{\mathrm{W}_{\mathrm{BM}}\right\}$ & $1.3 \mathrm{Bs}$ & $1.5 \mathrm{Bs}$ & $1.8 \mathrm{Bs}$ & $1.3 \mathrm{Bs}$ & $1.5 \mathrm{Bs}$ & $1.8 \mathrm{Bs}$ \\
\hline Ship speed (slow) $\left\{\mathrm{W}_{1}\right\}$ & $0.0 \mathrm{Bs}$ & $0.0 \mathrm{Bs}$ & $0.0 \mathrm{Bs}$ & $0.0 \mathrm{Bs}$ & $0.0 \mathrm{Bs}$ & $0.0 \mathrm{Bs}$ \\
\hline Cross wind (mild) $\left\{\mathrm{W}_{2}\right\}$ & $0.0 \mathrm{Bs}$ & $0.0 \mathrm{Bs}$ & $0.0 \mathrm{Bs}$ & $0.2 \mathrm{Bs}$ & $0.2 \mathrm{Bs}$ & $0.2 \mathrm{Bs}$ \\
\hline $\begin{array}{l}\text { Longitudinal flow current } \\
\{\mathrm{W} 3\}\end{array}$ & $0.1 \mathrm{Bs}$ & $0.0 \mathrm{Bs}$ & $0.0 \mathrm{Bs}$ & $0.1 \mathrm{Bs}$ & $0.0 \mathrm{Bs}$ & $0.0 \mathrm{Bs}$ \\
\hline Good aid to navigation $\{\mathrm{W} 4\}$ & $0.1 \mathrm{Bs}$ & $0.1 \mathrm{Bs}$ & $0.1 \mathrm{Bs}$ & $0.2 \mathrm{Bs}$ & $0.2 \mathrm{Bs}$ & $0.2 \mathrm{Bs}$ \\
\hline $\begin{array}{l}\text { Bottom surface }(\mathrm{h}<1.5 \mathrm{Ts}) \\
\{\mathrm{W} 5\}\end{array}$ & $0.1 \mathrm{Bs}$ & $0.1 \mathrm{Bs}$ & $0.1 \mathrm{Bs}$ & $0.1 \mathrm{Bs}$ & $0.1 \mathrm{Bs}$ & $0.1 \mathrm{Bs}$ \\
\hline $\begin{array}{l}\text { Waterway depth }(\mathrm{h}=1.3 \mathrm{Ts}) \\
\{\mathrm{W} 6\}\end{array}$ & $0.2 \mathrm{Bs}$ & $0.2 \mathrm{Bs}$ & $0.2 \mathrm{Bs}$ & $0.2 \mathrm{Bs}$ & $0.2 \mathrm{Bs}$ & $0.2 \mathrm{Bs}$ \\
\hline $\begin{array}{l}\text { Cargo hazard level (Low) } \\
\left\{\mathrm{W}_{7}\right\}\end{array}$ & $0.0 \mathrm{Bs}$ & $0.0 \mathrm{Bs}$ & $0.0 \mathrm{Bs}$ & $0.0 \mathrm{Bs}$ & $0.0 \mathrm{Bs}$ & $0.0 \mathrm{Bs}$ \\
\hline Total increase in width (Wi) & $0.5 \mathrm{Bs}$ & $0.4 \mathrm{Bs}$ & $0.4 \mathrm{Bs}$ & $0.8 \mathrm{Bs}$ & $0.7 \mathrm{Bs}$ & $0.7 \mathrm{Bs}$ \\
\hline $\begin{array}{l}\text { Ship speed increase (slow) } \\
\left(W_{P}\right)\end{array}$ & $1.4 \mathrm{Bs}$ & $1.0 \mathrm{Bs}$ & $1.0 \mathrm{Bs}$ & $1.4 \mathrm{Bs}$ & $1.0 \mathrm{Bs}$ & $1.0 \mathrm{Bs}$ \\
\hline $\begin{array}{l}\text { Bank clearance }\left(\mathrm{W}_{\mathrm{BG}}\right) \& \\
\left(\mathrm{~W}_{\mathrm{BR}}\right)\end{array}$ & $0.3 \mathrm{Bs}$ & $0.3 \mathrm{Bs}$ & $0.3 \mathrm{Bs}$ & $0.2 \mathrm{Bs}$ & $0.2 \mathrm{Bs}$ & $0.2 \mathrm{Bs}$ \\
\hline
\end{tabular}

Table 7

Channel Width Calculation by PIANC (in meters)

\begin{tabular}{lcccccc}
\hline The Design Element & \multicolumn{3}{c}{ PIANC 1997 } & \multicolumn{2}{c}{ PIANC 2014 } \\
\cline { 2 - 7 } & $\begin{array}{c}\text { Main } \\
\text { waterwa } \\
\mathrm{y}\end{array}$ & $\begin{array}{c}\text { Damietta } \\
\text { branch }\end{array}$ & $\begin{array}{c}\text { Behery \& } \\
\text { Nubaria }\end{array}$ & $\begin{array}{c}\text { Main waterway } \\
\text { Damietta } \\
\text { branch }\end{array}$ & $\begin{array}{c}\text { Behairy \& } \\
\text { Nubaria }\end{array}$ \\
\hline Ship maneuvering $2 \mathrm{~W}_{\mathrm{BM}}$ & $2.6 \mathrm{Bs}$ & $3.0 \mathrm{Bs}$ & $3.6 \mathrm{Bs}$ & $2.6 \mathrm{Bs}$ & $3.0 \mathrm{Bs}$ & $3.6 \mathrm{Bs}$ \\
\hline Increase in width $2\left[\mathrm{sum} \mathrm{W}_{\mathrm{i}}\right]$ & $1.0 \mathrm{Bs}$ & $0.8 \mathrm{Bs}$ & $0.8 \mathrm{Bs}$ & $1.6 \mathrm{Bs}$ & $1.4 \mathrm{Bs}$ & $1.4 \mathrm{Bs}$ \\
\hline Sloping channel edges $\left(\mathrm{W}_{\mathrm{BR}}\right)$ & $0.3 \mathrm{Bs}$ & $0.3 \mathrm{Bs}$ & $0.3 \mathrm{Bs}$ & $0.2 \mathrm{Bs}$ & $0.2 \mathrm{Bs}$ & $0.2 \mathrm{Bs}$ \\
\hline
\end{tabular}


Vol.42, No.1. January2023

\begin{tabular}{lllllll}
\hline Sloping channel edges $\left(\mathrm{W}_{\mathrm{BG}}\right)$ & $0.3 \mathrm{Bs}$ & $0.3 \mathrm{Bs}$ & $0.3 \mathrm{Bs}$ & $0.2 \mathrm{Bs}$ & $0.3 \mathrm{Bs}$ & $0.2 \mathrm{Bs}$ \\
\hline Total increase in width $(\mathrm{WP})$ & $1.4 \mathrm{Bs}$ & $1.0 \mathrm{Bs}$ & $1.0 \mathrm{Bs}$ & $1.4 \mathrm{Bs}$ & $1.0 \mathrm{Bs}$ & $1.0 \mathrm{Bs}$ \\
\hline Total waterway width $(\mathrm{W})$ & $5.6 \mathrm{Bs}$ & $5.4 \mathrm{Bs}$ & $6.0 \mathrm{Bs}$ & $6.0 \mathrm{Bs}$ & $5.9 \mathrm{Bs}$ & $6.4 \mathrm{Bs}$ \\
\hline
\end{tabular}

The values of the method developed by the

determine waterway channel parameters that fulfill Canadian Coast Guards (CCG) in 2001 to efficient maneuverability are listed in Table 8.

Table 8

Channel Width values By (CCG, 2001)

\begin{tabular}{clccc}
\hline No. & \multicolumn{1}{c}{ Design Element } & \multicolumn{2}{c}{ Design channel width values } \\
\cline { 3 - 5 } & & $\begin{array}{c}\text { River } \\
\text { Nile }\end{array}$ & $\begin{array}{c}\text { Damietta } \\
\text { branch }\end{array}$ & Behairy \& Nubaria \\
\hline 1 & Maneuvering lane width & $\begin{array}{c}2(1.5 \\
\text { Bs })\end{array}$ & $2(1.5 \mathrm{Bs})$ & $2(1.5 \mathrm{Bs})$ \\
\hline 2 & Increase due to traffic density & $0.4 \mathrm{Bs}$ & $0.2 \mathrm{Bs}$ & $0.2 \mathrm{Bs}$ \\
\hline 3 & Increase due to cross winds & $0.0 \mathrm{Bs}$ & $0.0 \mathrm{Bs}$ & $0.0 \mathrm{Bs}$ \\
\hline 4 & Increase due to cross currents & $0.0 \mathrm{Bs}$ & $0.0 \mathrm{Bs}$ & $0.0 \mathrm{Bs}$ \\
\hline 5 & Increase due to bank suction & $0.5 \mathrm{Bs}$ & $0.75 \mathrm{Bs}$ & $0.5 \mathrm{Bs}$ \\
\hline 6 & Increase due to navigation aids & $0.1 \mathrm{Bs}$ & $0.1 \mathrm{Bs}$ & $0.1 \mathrm{Bs}$ \\
\hline 7 & Increase due to cargo hazard & $0.0 \mathrm{Bs}$ & $0.0 \mathrm{Bs}$ & $0.0 \mathrm{Bs}$ \\
\hline 8 & Increase due to depth/draught ratio & $0.2 \mathrm{Bs}$ & $0.2 \mathrm{Bs}$ & $0.2 \mathrm{Bs}$ \\
\hline 9 & Increase due to bed surface & $0.1 \mathrm{Bs}$ & $0.1 \mathrm{Bs}$ & $0.1 \mathrm{Bs}$ \\
\hline Total width in terms of ship width & & $4.3 \mathrm{Bs}$ & $4.35 \mathrm{Bs}$ & $4.1 \mathrm{Bs}$ \\
\hline
\end{tabular}

\subsection{Through River Meanders}

Five approaches were discussed to estimate the appropriate increase in channel width within curved bends. The extra width is estimated as a multiple of (Bs) for all the approaches except that of the U.S. Army Corps of Engineers (1980) which requires the value of the deflection angle. Therefore, it was excluded. The extra width values recommended by these approaches are listed in Table 9. The table reveals that the values are largely disparate. They range between 2.5 and $20.0 \mathrm{~m}$. The values given by Boogaard [12] are the highest and those given by PIANC [13] are the lowest. However, the (CCG)
[15] and PIANC [14] approaches depend on the ship width (Bs) which this study is interested in. While, the (CCG) [15] gives higher values which mean more safety, PIANC [14] gives lower values which mean more economy. Therefore, the choice of which depends of the sound engineering judgment on the concerned meander. In our case studies, extra width values were preliminarily proposed. As for the implementation stage, these values should be estimated again based on the meander curvature and the design ship dimensions (length and width). Generally, the highest values should be applied in case of Damietta branch for its high sinuosity.

Table 9

Summary of the increase in Channel Width at Curved Bends

\begin{tabular}{lll}
\hline No. & Design method & Extra width at bends \\
\hline $\mathbf{1}$ & BOOGAARD, 1992 & $20.0 \mathrm{~m}$ \\
\hline $\mathbf{2}$ & U.S. ARMY, 1980 & Depends on the deflection angle \\
\hline $\mathbf{3}$ & PIANC, 1997 & $2.5 \mathrm{~m}$ \\
\hline $\mathbf{4}$ & CANADIAN, 2001 & $1.3 \mathrm{Bs}$ \\
\hline $\mathbf{5}$ & PIANC, 2014 & $2.5 \mathrm{~m}+0.4 \mathrm{Bs}$ \\
\hline
\end{tabular}

\subsubsection{Swept Path Geometry}

Regardless of the extra channel width at river bends and the swept track width, swept path geometry plays an important role in navigation safety. This is because the maneuvering ships in bends will remarkably turn away from its course more than that in straight segments. Therefore, the turning of vessels in bends has to be made at the proper time to prevent colliding with banks particularly when sailing against the flow current. In addition, ship control along the bend is more difficult because of the absence of navigation ranges (Kray) [16]. Therefore, the channel width is usually widened at bends to provide more maneuvering space. Herbich [6] concluded that the increase of channel width at bends is considered a function of a number of variables such as the deflection angle, radius of curvature, 
environmental conditions and the length, beam, and controllability of the design vessel. The entire amount of widening may be applied to the inner curve of the bend, or equally or unequally split on both sides of the channel bend to produce such an appropriate situation. The optimum alignment for the swept path would be reached when the transition of vessels between the straight and curved channel zones induce minimum asymmetric hydrodynamic forces on the vessel. To achieve such condition, transition between the straight and widened cross section in the bends should be made as gradual as possible to provide smooth change. In this case, the maximum rate of widening should be about one to twenty to secure smooth vessel transition between the straight and curved channel zones. To deal with such a condition, Kray [16] and Wallingford [17] suggested four different alternatives for channel widening and swept path geometry through bends as shown in Figs 6 and 7. This gradual transition between straight river segments and bends should be taken into account on the implementation of the new width upgrade reached by this research work.

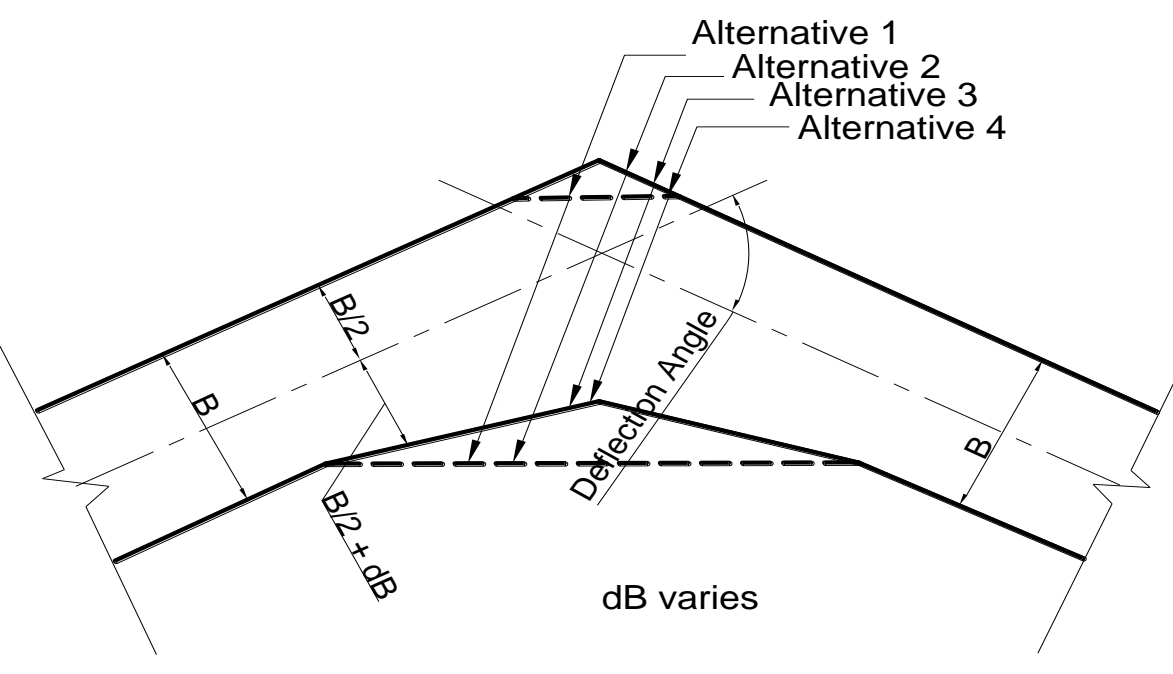

Fig. 6. Different Alternatives for Straight Line Turn

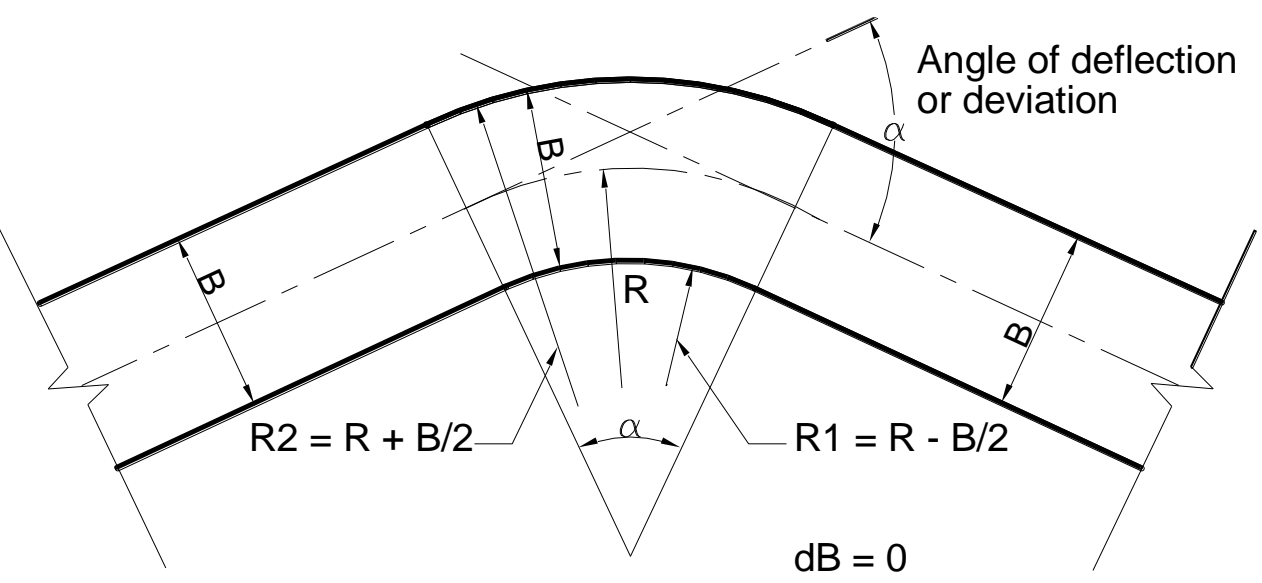

Fig. 7. Constant Width Turn

\section{Final Results and Discussion}

A summary of the final design widths calculated for one and two-way channels by the common design methods including straight river segments and meanders are listed in Table 10 below. Analyzing the results, the following could be pointed out:

1. Final proposed design width values are given for the navigable channels along the four 
selected River Nile waterways in both straight and meandering segments;

2. For design of a safe two-way navigable channel in straight river segments, the approach of PIANC, 2014 should be always recommended as it gives the biggest width value among the four approaches used;

3. For design of a safe one-way navigable channel in straight river segments, the approach of CCG, 2001 should be recommended as it gives the biggest width value;

4. In short, a designer should use CCG, 2001 for one-way navigable channel design and PIANC, 2014 for two-way design;

5. A meander having a radius of curvature " $r$ " less than 5 times the ship length "L" is considered sharp, whereas a meander of $5 \mathrm{~L}<\mathrm{r}<10 \mathrm{~L}$ is normal while a meander of $\mathrm{r}>10 \mathrm{~L}$ is considered a straight segment;

6. For a safe navigable channel at a sharp meander, an extra width value should be added to the width of the straight channel using approach CCG, 2001 as it gives the biggest value. In our chosen case studies, Damietta branch should have this extra value which equals $1.3 \mathrm{Bs}$;

7. For normal meanders, the extra width value given by PIANC, 2014 is recommended as it is safe enough to make room for the probable ship deviation;

8. In straight river reaches/segments, approach CCG, 2001 gives the least design width values for a two-way navigable channel, while approach PIANC, 2014 gives the biggest design width values;

9. In straight river reaches/segments, approach PIANC, 2014 gives the least design width values for a one-way navigable channel, while approach CCG, 2001 gives the biggest design width values;

\section{Summary and Conclusion}

The present applied research has upgraded the navigable channels currently used through the River Nile main waterway and other three smaller and narrower waterways; Damietta, El Rayah El Behairy, and El Nubaria Canal. The upgrade has targeted the design of safe navigable channels along river straight and meandering segments to accommodate broad ships of $15,11.6$, and $7.5 \mathrm{~m}$ widths. Three design methods were discussed for application namely; guideline, empirical and common. The first two were excluded because they don't consider river meanders in design. Only, the third (common) was considered. It has four design approaches; (Boogaard, 1992), (PIANC, 1997), (CCG, 2001), and (PIANC, 2014). They were all applied in design and their final results were analyzed and discussed. Finally, the results given by (CCG, 2001) and (PIANC, 2014) approaches were only taken into consideration because they turned out to achieve the safest ship navigability. Safety here means the widest channel. The wider the navigable channel is, the safer the channel is. CCG, 2001 proved safe in design of one-way channel, while PIANC, 2014 proved safe with twoway channels. Also, in sharp meanders, the extra width value given by CCG, 2001 was recommended while in normal meanders, the extra width value by PIANC, 2014 was recommended. Proposed computed width values in straight and meander segments were given in Table 10. Finally, the paper recommends CCG, 2001 and PIANC, 2014 to be applied in design of navigable channels in Egypt because they provide the highest safety in both straight and meandering river segments when they are compared with other design approaches developed so far.

\section{Acknowledgements}

The authors would like to thank Dr.\Ahmed Fahmy, an Emeritus Professor at the Hydraulic Research Institute (HRI) for his valuable support and advice. Indeed, he has proved to be a good support. The authors also wish to thank NRI administration for providing all the data necessary to complete this work.

\section{Conflict of Interests}

The authors declare that there is no conflict of interests.

\section{Funding}

This research did not receive any specific grant from funding agencies in the public, commercial, or not-for-profit sectors.

\section{References}

[1]

Studyrankersonline, $\quad 2018$ https://www.studyrankersonline.com/49115/w hat-are-advantages-of-waterways-as-meansof-transport (accessed Oct., 8th 2020).

[2] British Waterways, UK, 2003. Waterways and Development Plans. Report by Robin Evans. http://www.britishwaterways.co.uk/media/doc uments/publications/Waterways_and_Develop ment_Plans.pdf (accessed Oct., 8th 2020).

[3] Thoresen C. A. 1988. "Port design. Guidelines and recommendations", Tapir Publishers, 
Trondheim, 1988.

[4] Samuel, M. G., 2014. Limitations of Navigation through Nubaria Canal, Egypt. Journal of Advanced Research, Cairo University, Vol 5, pp 147-155, JAR March 2013.[http://dx.doi.org/10.1016/j.jare.2013.01. 006].

[5] Sadek, N., Salama, R. and Kamal, N. 2015. Effect of Bank Erosion and Bend Types on the Efficiency of Damietta Branch Navigation Path. International Water Technology Journal, IWTJ, Vol. 5 - No. 2, June 2015

[6] Herbich, J.B., 1986. Handbook of Coastal and Ocean Engineering. Volume 3, Harbors, Navigational Channels, 1986.

[7] NRI, 2004. Study of the Requirements of the Tourist Marinas between Cairo and Aswan until 2023. Report by Nile Research Institute (NRI), September 2004.

[8] Fahmy, A. A. and Fahmy W.A., 2018. Magnify Nile Cruise Activities through Nile River. Nile Water Science \& Engineering Journal, The Nile Basin Capacity Building Network for River Engineering, Delta Barrages, Egypt, Volume 11, Issue 1, Dec. 2018.

[9] El-Sersawy, H. and Ahmed, A.F., 2005. Inland Waterways Design Criteria and its Applications in Egypt. The ninth International Water Technology Conference, IWTC9, Sharm El-Sheikh, Egypt, 2005.

[10] Prsic, M., Carevic, D. \& Brcic, D., 2011. Determining Inland Waterway Parameters with Application to the Sava River. PROMET - Traffic \& Transportation. 23.10.7307/ ptt. V23i2.1421, 2011.

[11] USACE, 1980. Engineering and DesignLayout and Design of Shallow-Drift

and (PIANC, 2014))

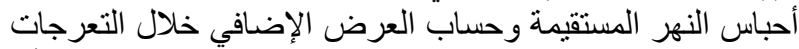

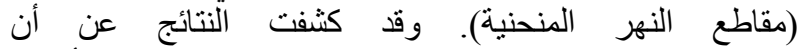
المنهجيتين (CCG, 2001) and (PIANC, 2014) قد أعطنا عرض القناة الأكثر أمانًا في حالتي القنوات المستقيمة أحادية

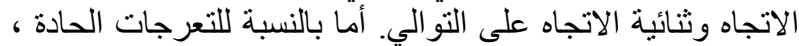
(CCG, فقد تم تفضيل قيمة العرض الإضـافي المعطى بوانيل

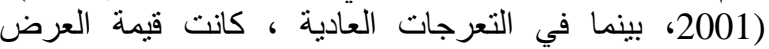
الإضافي المحسوب بالمنهجية (PIANC, 2014) أفضل. والخيرة وأخيرًا

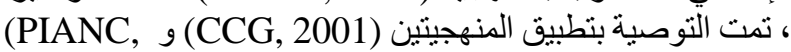

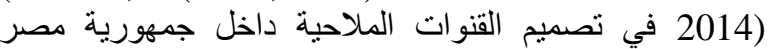
العربية ، لأنهما توفران أعلى درجات الأمان في كل من أحباس داخل

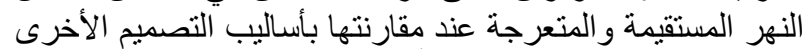

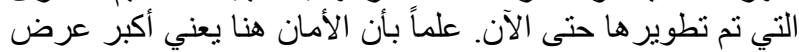
للقناه الملاحية يمكن أن تعطيه طرئ الان علم بان التصميم المتاحة.
Waterways. U.S. Army Corps of Engineers, Engineering Manual 1110-2-1611, Washington, DC, December 1980.

[12] Boogaard, A. 1992. Hydraulic Studies on the Nile River and its Structures, Phase II. Delft Hydraulics of the Netherlands and the Hydraulic and Sediment Research Institute, Fairway Dimensions, IWT Course, Feb. 1992.

[13] PIANC, 1997. Approach Channels: A Guide for Design. Final Report of the Joint PIANCIAPH Working Group II-30 in cooperation with IMPA and IALA, Supplement to Bulletin 95, Brussels, June.

[14] PIANC, 2014. Harbor approach Channels Design Guidelines. Maritime Navigation Commission, Report No. 121.

[15] CCG, 2001. Safe Waterways. A Users Guide to the Design, Maintenance and Safe Use of Waterways, Part 1 (a) Guidelines for the Safe Design of Commercial Shipping Channels, Software User Manual Version 3.0. Waterways Development Division, Fisheries and Oceans Canadian Coast Guard, Canada, Dec, 2001.

[16] Kray, C.J., 1973. Design of Ship Channels and Maneuvering Areas. Journal of Waterways, Harbors and Coastal Engineering Division, Vol. 99, No. WW1, pp. 89-110, ASCE, Feb. 1973.

[17] Wallingford, H.R., 1996. Guidelines for the Hydraulic and Navigational Design of Approach Channels. Wallingford, Oxford shire OX10 8BA, Report No SR 475, July 1996.

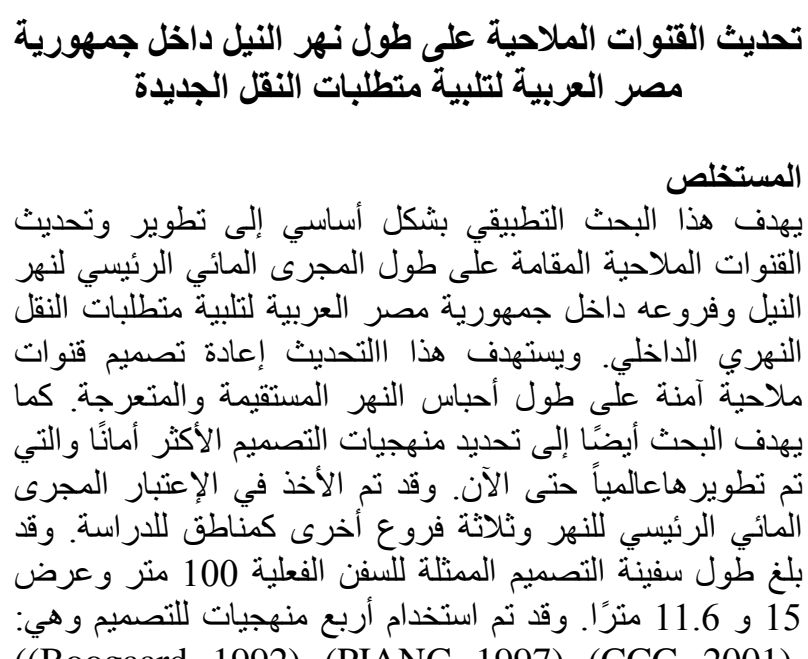

((Boogaard, 1992), (PIANC, 1997), (CCG, 2001), 
Vol.42, No.1. January2023

Table 10

Final Recommended Navigable Channel widths

\begin{tabular}{|c|c|c|c|c|c|c|c|c|c|c|c|c|}
\hline \multirow[b]{2}{*}{$\begin{array}{l}\text { Type of Proposed } \\
\text { Navigable Channel }\end{array}$} & \multicolumn{2}{|c|}{$\begin{array}{c}\text { River Nile Main } \\
\text { Waterway }\end{array}$} & \multicolumn{2}{|c|}{ Damietta branch } & \multicolumn{2}{|c|}{ El Rayah El Behairy } & \multicolumn{2}{|c|}{ El Rayah El Behairy } & \multicolumn{2}{|c|}{ El Nubaria Canal } & \multicolumn{2}{|c|}{ EI Nubaria Canal } \\
\hline & \multicolumn{2}{|c|}{ Two-way Channel } & \multicolumn{2}{|c|}{ Two-way Channel } & \multicolumn{2}{|c|}{ Two-way Channel } & \multicolumn{2}{|c|}{ One-way Channel } & \multicolumn{2}{|c|}{ Two-way Channel } & \multicolumn{2}{|c|}{ One-way Channel } \\
\hline $\begin{array}{l}\text { Range of Waterway Width } \\
\text { (m) }\end{array}$ & \multicolumn{2}{|c|}{ From 300 to 1000} & \multicolumn{2}{|c|}{ From 250 to 500} & \multicolumn{2}{|c|}{ From 50 to 75} & \multicolumn{2}{|c|}{ From 50 to 75} & \multicolumn{2}{|c|}{ From 30 to 55} & \multicolumn{2}{|c|}{ From 30 to 55} \\
\hline $\begin{array}{l}\text { Proposed Ship width (Bs) } \\
\text { (m) }\end{array}$ & \multicolumn{2}{|c|}{15.00} & \multicolumn{2}{|c|}{11.60} & \multicolumn{2}{|c|}{11.60} & \multicolumn{2}{|c|}{11.60} & \multicolumn{2}{|c|}{11.60} & \multicolumn{2}{|c|}{7.50} \\
\hline $\begin{array}{l}\text { Proposed Ship Length (L) } \\
\text { (m) }\end{array}$ & \multicolumn{2}{|c|}{100.00} & \multicolumn{2}{|c|}{100.00} & \multicolumn{2}{|c|}{100.00} & \multicolumn{2}{|c|}{100.00} & \multicolumn{2}{|c|}{100.00} & \multicolumn{2}{|c|}{51.00} \\
\hline Channel Feasibility & \multicolumn{2}{|c|}{ Feasible } & \multirow{2}{*}{\multicolumn{2}{|c|}{$\begin{array}{c}\text { Feasible } \\
\text { Curvature raduis "r" < } \\
\text { 5L No of Sharp } \\
\text { Bends }=8\end{array}$}} & \multicolumn{2}{|c|}{ Infeasible } & \multirow{2}{*}{\multicolumn{2}{|c|}{ Feasible }} & Infeas & ble & Feas & \\
\hline Meander Status & Not sl & & & & Not $\mathrm{s}$ & $\operatorname{arp}$ & & & Not sh & $\operatorname{arp}$ & Not $\mathrm{s}$ & $\operatorname{arp}$ \\
\hline Common Design Methods & $\begin{array}{l}\text { Coefficient } \\
\text { "C" }\end{array}$ & $\begin{array}{l}\text { Channel } \\
\text { Width = } \\
\mathrm{C} \times \mathrm{Bs}\end{array}$ & $\begin{array}{l}\text { Coefficient } \\
\text { "C" }\end{array}$ & $\begin{array}{l}\text { Channel } \\
\text { Width = } \\
\text { Cx Bs }\end{array}$ & $\begin{array}{l}\text { Coefficient } \\
\text { "C" }\end{array}$ & $\begin{array}{l}\text { Channel } \\
\text { Width = } \\
\mathrm{C} \times \mathrm{Bs}\end{array}$ & $\begin{array}{l}\text { Coefficient } \\
\text { "C" }\end{array}$ & $\begin{array}{l}\text { Channel } \\
\text { Width = } \\
\text { Cx Bs }\end{array}$ & $\begin{array}{l}\text { Coefficient } \\
\text { "C" }\end{array}$ & $\begin{array}{l}\text { Channel } \\
\text { Width = } \\
\mathrm{C} \times \mathrm{Bs}\end{array}$ & $\begin{array}{l}\text { Coefficient } \\
\text { "C" }\end{array}$ & $\begin{array}{l}\text { Channel } \\
\text { Width = } \\
\mathrm{C} \times \mathrm{Bs}\end{array}$ \\
\hline BOOGAARD (1992) & 4.50 & 67.50 & 4.50 & 52.20 & 4.50 & 52.20 & 3.50 & 40.60 & 4.50 & 52.20 & 3.50 & 26.25 \\
\hline PIANC (1997) & 5.60 & 84.00 & 5.60 & 64.96 & 6.00 & 69.60 & 3.80 & 44.08 & 6.00 & 69.60 & 3.80 & 28.50 \\
\hline CANADIAN (2001) & 4.30 & 64.50 & 4.35 & 50.46 & 4.10 & 47.56 & 3.90 & 45.24 & 4.10 & 47.56 & 3.90 & 29.25 \\
\hline PIANC (2014) & 6.00 & 90.00 & 5.90 & 68.44 & 6.40 & 74.24 & 2.60 & 30.16 & 6.40 & 74.24 & 2.60 & 19.50 \\
\hline $\begin{array}{l}\text { Final Average Channel } \\
\text { Width }\end{array}$ & & & & & & & & & & & & \\
\hline $\begin{array}{l}\text { Through straight river } \\
\text { segments }\end{array}$ & 90. & & 69.0 & & & & 46.0 & & & & 30. & \\
\hline Through river meanders & $99 .($ & & 85.0 & & & & 49.0 & & & & 30. & \\
\hline
\end{tabular}

